\title{
Capital Optimization Through an Innovative CVA Hedge
}

\author{
Michael Hünseler and Dirk Schubert
}

\begin{abstract}
One of the lessons of the financial crisis as of late was the inherent credit risk attached to the value of derivatives. Since not all derivatives can be cleared by central counterparties, a significant amount of OTC derivatives will be subject to increased regulatory capital charges. These charges cover both current and future unexpected losses; the capital costs for derivatives transactions can become substantial if not prohibitive. At the same time, capital optimization through CDS hedging of counterparty risks will result in a hedge position beyond the economic risk ("overhedging") required to meet Basel II/III rules. In addition, IFRS accounting rules again differ from Basel, creating a mismatch when hedging CVA. Even worse, CVA hedging using CDS may introduce significant profit and loss volatility while satisfying the conditions for capital relief. An innovative approach to hedging CVA aims to solve these issues.
\end{abstract}

Keywords CVA $\cdot$ Hedging $\cdot \mathrm{CDS} \cdot$ Contingent financial guarantee $\cdot$ Risk charges $\cdot$ OTC derivatives

\section{Preface}

In the following the nexus between credit risk (counterparty risk), liquidity, and market risk is analyzed and a solution with respect to CVA hedging of OTC derivative contracts is proposed.

The starting point is the consideration of collateral and its respective recognition in different but "basic" financial instruments like repos and (partially un-) collateralized

\footnotetext{
M. Hünseler $(\bowtie)$

Credit Portfolio Management, Assenagon Asset Management S.A., Zweigniederlassung München, Prannerstrae 8, 80333 Munich, Germany

e-mail: michael.huenseler@assenagon.com

D. Schubert

Financial Services KPMG AG Wirtschaftsprüfungsgesellschaft, The Squaire, Am Flughafen, 60549 Frankfurt am Main, Germany

e-mail: dschubert@kpmg.com 
OTC derivative contracts as well as the comparison to corresponding uncollateralized financial instruments like money market loans or uncollateralized OTC derivative contracts. The role of collateral is analyzed with respect to its legal basis, its treatment in Financial Accounting (IFRS, refer to [4]) and regulatory reporting according to Basel II/III (cf. [1, 2]).

The analysis leads to a definition of the concept of liquidity and its relation to the use of collateral in financial markets. As will be shown, the concept of liquidity, inherent in the legal framework related to collateral of basic financial instruments, can be considered as a transformation of secured into unsecured financing and vice versa. Moreover, with respect to the associated valuation and risk the liquidity transformation exhibits similarities to the concept of wrong-way risk. The transformation of unsecured into secured financing can be used to derive new types of financial instruments, e.g. in the application to CVA hedging issues of OTC derivative contracts. In this case the hedging instrument also solves the issue of disentangling funding value adjustments (FVA) and counterparty value adjustments (CVA), which is intensively discussed by practitioners in context with the pricing of OTC derivatives.

\section{The Role of Collateral in OTC Contracts and Its Legal Basis}

In the following the main legal basis with respect to the role of collateral is outlined.

\subsection{The Role of Legal Versus Economic Ownership}

There are two main properties which are of relevance in connection with the role of collateral, the transfer of legal ownership (i.e. the possibility of "re-hypothecation") in contrast to the economic ownership and the value of the collateral.

By entering into a repurchase agreement the legal title to the securities is transferred to the counterparty but economically the securities stay with the selling counterparty since the buying counterparty has the obligation to compensate the selling counterparty for income (manufactured payments) associated with the securities and to redeliver the securities. In case of an Event of Default, both obligations terminate. The treatment in an Event of Default provides that the residual claim is settled in cash and determined taking into account the cash side as well as the value of the collateral. In this case the obligation to redeliver securities transferred as collateral expires and the buying counterparty remains the legal owner. Thus the price risk of the collateral (uncertainty of value) is entirely borne by the legal owner.

In case of (only) economic ownership, e.g. a pledge, this is not necessarily the case, since the treatment in an Event of Default differs as e.g. this kind of "collateral" is part of the bankrupt/legal estate and therefore underlying the insolvency procedure. 
Despite these legal differences, the regulatory rules according to Basel II/III and the accounting rules under IFRS also require different treatment of collateral. In general IFRS follows the economic ownership concept irrespective of the legal basis of the collateral while Basel II/III rather follows the legal ownership concept.

\subsection{Affected Market Participants}

Not all market participants are affected by the same accounting and regulatory rules. Banks have to follow IFRS and Basel II/III rules, while e.g. investment funds are not affected by Basel II/III rules but are governed by investment fund legislation, e.g. UCITS directive. These different legal frameworks for market participants impact the usage of collateral in OTC contracts, e.g. the assets of an investment fund under UCITS represent special assets and the use of repos and cash collateral is limited. In addition, these investment funds have no access to sources of liquidity other than the capital paid which limits the use of cash and the provision of cash collateral in context of derivatives exposure. For example, cash collateral received from OTC derivative contracts has to be kept in segregated accounts and cannot be used for any kind of (reverse) repo transaction. Alternatively, the use of a custodian for optimizing the provision of cash collateral can be considered.

\subsection{Financial Instruments Involving Collateral and Standard Legal Frameworks (Master Agreements)}

Analyzing the legal basis of collateral facilitates the definition of liquidity and liquidity transformation.

\subsubsection{Derivatives Under ISDA Master Agreement}

The type and use of collateral are governed in the CSA (credit support annex), which represents an integral part of the ISDA Master Agreement framework ${ }^{1}$ and cannot be considered separately. The ISDA Master Agreement forms the legal framework and is applicable for the individual derivative contracts supplemented by the CSA. For example, default netting in the Event of Default (default of a counterparty) is governed by the ISDA Master Agreement including the netting of the collateral which in turn is defined in the CSA. The CSA defines the type(s) of collateral and the terms of margining/posting, while the transfer of the legal ownership is governed in the ISDA Master Agreement. In general ISDA Master Agreements contracted under English Law provide the legal transfer of ownership of the collateral while ISDA Master

\footnotetext{
${ }^{1}$ ISDA®, International Swaps and Derivatives Association, Inc., 2002 Master Agreement.
} 
Agreements contracted under New York Law do not. In the latter re-hypothecation, i.e. the re-use of the received collateral for counterparties is prohibited.

In case of ISDA Master Agreements under English Law the derivative contracts are terminated in case of an Event of Default and the collateral is taken into account in order to determine the residual claim. The determination of the residual claim is performed independently from the estate of the insolvent party.

\subsubsection{Repos Under GMRA}

A repo or repurchase agreement under GMRA ${ }^{2}$ can economically be seen as a collateralized loan and is typically motivated by the request for cash. In case of repurchase agreements, the legal title to the securities provided as collateral is transferred to the counterparty (buyer) in exchange of the desired cash (purchase price). The credit risk and liquidity of the underlying securities determine the haircut in the valuation of the collateral. Adverse changes in the inherent credit risk of the securities are offset by an increase in haircut and induce in terms of margining additional posting of collateral to the counterparty. At maturity the securities are legally transferred back to original owner (seller) in exchange for the agreed cash amount (repurchase price). In case of a counterparty's default the securities are not returned and the recovery risk of the securities is borne by their legal owner (the buyer).

\subsubsection{Securities Lending Under GSLMA}

In contrast to a repo, a securities lending under GSLMA ${ }^{3}$ is motivated by the need for securities but is (commonly) also a secured financing transaction since the securities as well as the collateral are legally transferred to the respective counterparty. In the secured case the collateral can be cash or other securities.

\subsection{Credit and Counterparty Risk Related to Collateral}

Consider the case that Bank 1 and Bank 2 enter into a repo transaction, where Bank 2 receives cash from Bank 1 in return for securities. There are two features of importance: Bank 1 needs cash funding, which requires an assumption with respect to the sources of funding, e.g. central bank, deposits. The corresponding assumption represents a component in determining the profitability of the repo. An additional feature is the inherent wrong-way risk within the repo transaction. In this case the

\footnotetext{
${ }^{2}$ Sifma, Securities Industry and Financial Markets Association and ICMA, International Capital Market Association, 2011 version Global Master Repurchase Agreement.

${ }^{3}$ ISLA, International Securities Lending Association, Global Master Securities Lending Agreement, Version: January 2010.
} 
wrong-way risk for Bank 1 is defined as an adverse correlation (positive in the example above) between counterparty credit risk toward Bank 2 and market value of the collateral (securities). Assuming a long position in the underlying securities (collateral) for Bank 1, the wrong-way risk constitutes a decrease in value of the securities (collateral) and a simultaneous decrease in credit worthiness of Bank 2. In this case the risk for Bank 1 is the failure of Bank 2 in balancing the collateral posting. Since in a repo transaction the legal ownership is transferred to Bank 1, the net risk position comprises the price risk (in the Event of Default of Bank 2) associated with the collateral (securities) including the haircut and the cash claim (cash loan). A similar rationale holds in case of a short position in securities (collateral) since an event of default affects the ability to post as well as to return posted collateral. Similar considerations hold in case of a (partially) collateralized OTC derivative transaction, e.g. an interest rate swap.

\section{Terms of Liquidity and Definition of Liquidity Transformation}

Dealing with the concept of liquidity reveals that the term is not defined consistently or not uniformly in financial regulations. A natural way is to adopt legal definitions.

\subsection{Terms of Liquidity}

There is a variety of definitions for the term liquidity, e.g. meeting payment obligations (liquidity of an entity), liquid marketable securities (ability to buy and sell financial instruments), etc. The analysis above reveals the interdependence of "liquidity" and counterparty credit risk, respectively credit risk. As such liquidity of an entity can be considered as the relatively measured ability for a bank to raise cash from a credit line or in return of collateral which in turn is dependent on the liquidity of financial instruments. The collateral itself is only accepted if the price of the collateral can be reliably determined, e.g. it is traded with sufficient frequency on an active market.

\subsection{Comparison of Secured and Unsecured Financing}

The best way to illustrate the concept formation of liquidity respectively liquidity transformation is the comparison of unsecured and secured financing in case of a default event. Continuing the example above, the following comparison considers Bank 1 as cash provider. 
1. Financial action

Secured: Exchange of cash versus collateral

Unsecured: Paying out cash of a loan granted

2. Prerequisite and term of liquidity

Secured: "Liquid" collateral (price of collateral can be reliably determined)

Unsecured: Credit line loan illiquid - not marketable

3. Net (relative) risk position in case of default

Secured: $\quad$ Market value of collateral: Default Probability (issuer of the security received as collateral) $\times$ recovery rate of collateral $\times$ amount of collateral (proximate representation via haircut)

Unsecured: Recovery rate of cash loan $\times$ exposure at default (EAD)

4. Relation to estate of insolvent party

Secured: Only residual claim part of the estate of the insolvent party but amount of residual claim is determined independently of the estate of the insolvent party

Unsecured: Entirely part of the estate of the insolvent party

5. Risk

Secured: Credit risk of collateral issuer, correlation between counterparty risk and price of collateral (wrong-way risk in an adverse case)

Unsecured: Credit risk with respect to the borrower

Note that in the comparison above the net (relative) risk position in both cases, for secured and unsecured financing, involves a recovery rate but the associated risk relates to different counterparties. In case of secured financing the default risk is coupled with the recovery risk (price risk) of the collateral and the risk position can be settled promptly in case of a default while in case of the unsecured financing the settlement of the recovery depends on the insolvency process.

This comparison in particular shows that the credit risk toward the counterparty in the unsecured financing transaction being rather illiquid is opposed to the market value risk of the received collateral which is assumed to be liquid in the secured case plus the correlation of this risk and the credit risk of the issuer of the securities taken as collateral. In the adverse case this risk correlation is also known as "wrong way risk".

\subsection{Liquidity Transformation}

Accordingly considering liquidity as an absolute quantity is not useful but as a relative quantity: a relation between secured financing and unsecured financing, which we term liquidity transformation. This transformation is not independent from credit 
respective counterparty risk, since each type of financing is associated with a different type of credit risk. The liquidity transformation is dependent on the type of entity and cannot be considered separately from its legal status. A bank has different access and a higher degree of freedom to assign liquidity irrespective of the purpose than, e.g. an investment fund.

\section{New Approach to CVA Hedging}

The new CVA hedging approach outlined below represents a response to current challenges in banking regulation and reveals the importance of liquidity transformation. The legal-based background described above can be used to explain current challenges of banking industry if in addition to prevailing market conditions the regulatory and financial accounting environments are taken into account. Recent environmental changes have immediate impact on banking business activities concerning counterparty risk and can be summarized as follows:
Regulatory and Accounting Aspects
Business Impact
- CCR (counterparty credit risk) is under scrutiny of regulators and financial accounting standard set- ters.
- Increased regulatory require- ments on bilateral collateraliza- tion and clearing.
- Increased (regulatory) capital requirements for banks.
- Increased P/L volatility due to IFRS fair value accounting rules (e.g. recognition of CVA).
- Increased (regulatory) capital affects resp. limits banking busi- ness.
- Intensified application of credit risk mitigation by netting, collateraliza- tion and hedging.
- Increased demand for secured (col- lateralized) transactions
- Increased demand for (liquid / high quality) collateral.
- Increased demand for optimization of collateral.

\subsection{Issue}

During the financial crises regulators and financial accounting setters notified the relevance of counterparty credit risk in OTC derivative contracts. In response to this relevance several regulatory (legislative) initiatives have been undertaken like central clearing, increased regulatory capital, etc. These impacted the business of banking industry in several ways: intensified use of credit risk mitigation techniques and increased demand for secured transactions (demand for collateral, cf. also [3]). 
Despite the environmental changes credit risk mitigation is and remains essential to continue banking business. Considering equity as a scarce source, banks are forced to tighten their credit exposure in order to offset the increase in capital charges due to increased costs for CCR and other factors. The tightening of credit exposure limits banking business and increases the demand for credit risk mitigation techniques (including hedging).

The mentioned regulatory changes induce tremendous costs for the banking industry. Therefore, managing credit risk by commonly used CDS hedging strategies becomes expensive in presence of the banking regulation, so credit risk management will be rearranged, e.g. more offsetting positions, avoiding exposures (reducing limits) or transferred ("outsourced") outside the regulated banking sector, so e.g. investment funds are in a favorable position to manage a bank's risks. This also holds for counterparty credit risk following the idea to transfer counterparty credit risk to market participants outside the banking sector that are in the situation to manage this risk economically at lower cost than banks.

Additionally banking industry is faced with various different regulations. With respect to counterparty credit risk a bank is confronted with conflicting objectives resulting from regulatory requirements, i.e. Basel II/III, and financial accounting rules. Therefore, under current regulatory and accounting requirements banks cannot manage counterparty credit risk (CCR) of derivatives uniformly in respect of capital requirements and P/L volatility. This results from the fact that the hedging of counterparty credit risk exposure (in terms of Basel II/III requirements) requires the hedging of current and future changes of exposure, while IFRS only considers current exposure. So a bank is required to hedge more than the current exposure ("overhedging") in terms of Basel II/III. But since hedging is mainly carried out by derivatives as CDS, these CDS cause P/L volatility under IFRS, since derivatives are recognized at fair value through $\mathrm{P} / \mathrm{L}$.

As described above secured and unsecured financing is common practice in finance industry and can be observed in counterparty credit risk of OTC derivative contracts. As illustrated below in an uncollateralized OTC derivative trade between Bank A and counterparty B, the parties enter into an unsecured financing relationship. If the market value of the derivative trades of Bank A against counterparty $\mathrm{B}$ increases then Bank A is exposed to counterparty credit risk (CVA risk). Bank A implicitly provides counterparty B an illiquid credit line in the sense, that the positive exposure amount ("market value") is recognized as an asset which becomes a legal claim in the Event of Default. This exposure is not a tradable asset but needs to be funded thus it could be interpreted as an illiquid asset. In comparison to standard banking credit business, this credit line is unlimited and varies with the market value of the underlying derivative trades, which implies also unlimited funding. The current focus of discussions and research concentrates on measuring counterparty credit risk by exposure and default probability modeling (CVA risk) and the assignment of the appropriate discount rate for the OTC derivative trades reflecting the FVA. The discussed approaches share the following assumptions: 
1. No market segmentation between collateralized and uncollateralized OTC derivative trades.

2. The application of the absence of arbitrage principle, which in particular assumes the unlimited use of liquidity by market participants.

3. Liquidity risk and credit risk cannot be decoupled.

4. The coincidence of counterparty credit risk and credit risk, which can be both hedged by the same type of hedging instruments (credit default swaps (CDS), contingent credit default swaps (CCDS)).

5. The absence of transaction costs, which are represented by regulatory costs (e.g. CVA risk charges according to Basel II/III) and reported earnings volatility under IFRS stemming from fair value accounting of counterparty fair value adjustments and derivative valuation.

These ideal assumptions are not necessarily met in reality, therefore alternative approaches have to be explored.

\subsection{Solution}

Since banks with significant activities in derivatives markets can be affected quite heavily by the aforementioned issues, a workable solution should solve the build-in conflict of regulatory and accounting requirements. As a result, the solution contributes to an improved competitiveness of the bank in the context of derivative risk management, derivatives' pricing, and support the bank in conducting derivatives business which will ultimately benefit the economy as a whole. Consequently, a potential solution is about developing a financial instrument ("credit risk mitigating instrument") which reduces the Basel II/III CCR capital requirements and CVA risk charge without resulting in additional P/L volatility under IFRS. Such a financial instrument represents a solution to the issues described above since it creates:

- A market for counterparty credit risk exposure

The positive exposure of an (un-) collateralized derivative portfolio can be considered as an illiquid asset in contrast, e.g. to a liquid issuance of a bank.

- A new asset type-make the derivative claim a tradable asset

The idea is to make this exposure tradable in exchange for collateral by means of an instrument like Collateral Support Annex (CSA) which directly refers to the possibly varying positive exposure of a derivative portfolio.

- An active market involving banks and investment funds

In order to increase liquidity and to avoid only a shift of capital charges from one institution to another due to hedging activities for the taken credit risk a transfer to a market participant outside the banking sector is considered.

The outline of a solution follows the liquidity transformation. The unsecured financing for OTC derivatives would be represented by uncollateralized OTC derivatives while secured financing requires corresponding posting of collateral. Pursuing the 


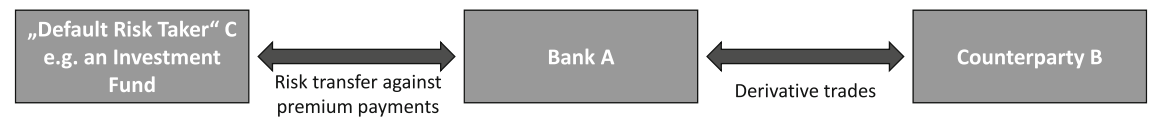

Fig. 1 Secured OTC derivative transaction

aim of decoupling liquidity and counterparty risk, at least three parties are necessary to involve as demonstrated in the analysis on repos above. Therefore, the aim could not be achieved by cash collateralized bilateral OTC derivatives commonly used in the interbank market, since there is still a one-to-one correspondence between liquidity requirements (e.g. cash collateral postings) and counterparty risk. Additionally a bilateral CSA assumes that both counterparties have unlimited access to liquidity, which represents a difficulty if counterparty B is a corporate according to its limited access to collateral/cash. Therefore a secured financing transaction for CVA hedging has to be structured differently.

The secured financing transaction outlined in Fig. 1 involves a third party "Default Risk Taker" C, who is posting collateral to Bank A on behalf of counterparty B, i.e. whenever the value of the derivative trade is positive for Bank A. This transaction represents a tri-party CSA and works similar to a margining. The transaction between "Default Risk Taker" C and Bank A is an asymmetric contract, since if the value of the derivative trade is negative for Bank A, no collateral is provided to or by Bank A. In case of a default of counterparty B the posted collateral is not returned to "Default Risk Taker C". The structure described above represents the appropriate complement for a bilateral uncollateralized OTC derivative transaction.

The structure reveals the concept of liquidity transformation including a decoupling of liquidity and counterparty risk, since by using the contract the unsecured financing transaction is transformed into a secured financing transaction. Referring to the comparison of unsecured and secured financing described above (cf. Sect. 2.3), the proposed structure goes one step further by linking both market segments and transforming liquidity within one single transaction. By definition of the liquidity transformation, the transaction exchanges different types of credit risk.

\subsection{Application}

The table in Fig. 2 shows the contemplation of the new CVA hedge structure (cash collateral with contingent financial guarantee, "CCCFG"; for more detail refer to [5]) to existing credit risk mitigation techniques applied in the banking industry. Its main features are summarized as follows:

- The proposed structure represents a credit risk mitigating instrument, which reduces the Basel II/III CCR capital requirements CVA risk charge, since the cash collateral provided by a third party is permitted under Basel II/III requirements and reduces the exposure according to Basel II/III. 


\begin{tabular}{l|l|l|l|l}
\hline Aspects & Netting & $\begin{array}{l}\text { Bilateral } \\
\text { Collateralization }\end{array}$ & $\begin{array}{l}\text { Credit Default } \\
\text { Swap (CDS) } \\
\text { based hedges }\end{array}$ & $\begin{array}{l}\text { Contingent } \\
\text { CDS }\end{array}$ \\
\hline Economics & $\begin{array}{l}\text { Reduction of the } \\
\text { risk position by } \\
\text { netting of } \\
\text { exposures }\end{array}$ & $\begin{array}{l}\text { Counterparty risk is } \\
\text { reduced by posted } \\
\text { (cash) collateral }\end{array}$ & $\begin{array}{l}\text { Hedges of the } \\
\text { counterparty } \\
\text { default risk }\end{array}$ & $\begin{array}{l}\text { Hedges of the } \\
\text { counterparty } \\
\text { default and } \\
\text { exposure risk }\end{array}$ \\
\hline $\begin{array}{l}\text { Operational } \\
\text { - Legally } \\
\text { enforceable }\end{array}$ & $\begin{array}{l}\text { - Default netting } \\
\text { (ISDA } \\
\text { standard) }\end{array}$ & $\begin{array}{l}\text { Changes in OTC } \\
\text { - Rerivative contracts } \\
\text { issue for corporates) }\end{array}$ & $\begin{array}{l}\text { Requires liquidity (an } \\
\text { required } \\
\text { - Liquid CDS }\end{array}$ & $\begin{array}{l}\text { No Delta } \\
\text { Hedging } \\
\text { required } \\
\text { Less liquid } \\
\text { than CDS }\end{array}$ \\
\hline $\begin{array}{l}\text { Financial } \\
\text { Accounting } \\
\text { (IFRS) }\end{array}$ & $\begin{array}{l}\text { IAS 32 requires } \\
\text { simultaneous } \\
\text { payment- and } \\
\text { default netting }\end{array}$ & $\begin{array}{l}\text { Posted collateral } \\
\text { reduces fair value } \\
\text { volatility }\end{array}$ & $\begin{array}{l}\text { Fair value } \\
\text { accounting through } \\
\text { P\&L }\end{array}$ & $\begin{array}{l}\text { Fair value } \\
\text { accounting } \\
\text { through P\&L }\end{array}$ \\
\hline $\begin{array}{l}\text { Regulatory } \\
\text { (Basel II/III) }\end{array}$ & $\begin{array}{l}\text { Basel differs } \\
\text { from IFRS due } \\
\text { to default netting }\end{array}$ & $\begin{array}{l}\text { Reduces derivative } \\
\text { exposure (credit risk } \\
\text { mitigation) }\end{array}$ & $\begin{array}{l}\text { Credit risk mitiga- } \\
\text { tion if requirements } \\
\text { are met }\end{array}$ & $\begin{array}{l}\text { Credit risk miti- } \\
\text { gation if require- } \\
\text { ments are met }\end{array}$
\end{tabular}

Fig. 2 Current and new approaches for credit risk mitigation in banking industry

- Accordingly there is immediate regulatory capital relief, which results in an immediate saving respectively reduction of the cost of equity.

- The proposed structure simultaneously qualifies as a contingent financial guarantee such that there is no additional P/L volatility under IFRS. In particular the financial guarantee accounting under IFRS applies to the proposed structure by considering the case of default. In case of a default of OTC derivatives contracted under ISDA the final claim is determined. The financial guarantee under IFRS comes into effect only at default_not before_-and "guarantees" the value of the final claim, which is recognized at amortized cost and physically transferred to counterparty $\mathrm{C}$ in return for cash to Bank A. The final claim takes into account the posted collateral until the Event of Default. For a more detailed description refer to [5].

- As becomes apparent from the table above the new CVA hedge structure is a separate financial instrument. This cash collateral with contingent financial guarantee ("CCCFG") differs from a "traditional" CDS/CCDS, since the collateral postings are directly related to the counterpartys exposure. In case of a CCDS the cash collateral refers to the CCDS contract itself reflecting its value and there is no direct legal link to the exposure subject to hedging by the CCDS. Additionally CCDS represents derivatives in terms of IFRS and not necessarily qualify as credit risk mitigation instrument under Basel II/III. If a CCDS qualifies as credit risk mitigation instrument it applies to the Basel II/III PD, while the CCCFG directly affects the exposure.

- Operationally the new CVA hedging instrument is more effective and less costly than CDS delta hedging approaches, since a constant adjustment of a hedging position using CDS induces transaction costs and depends also on the gamma of the risk position. Accordingly the hedge position is never "perfect". 
- The approach is flexible with respect to counterparty risk profiles, since it applies to linear and nonlinear exposure profiles.

- The legal framework of the approach is based on ISDA, which ensures the operational effectiveness in terms of legal certainty and the recognition in front office IT systems in order to process the transaction.

- It has to be noticed that investment funds have to observe certain rules and regulations which come with the specific fund format and domicile. For example, funds fulfilling the highest standards are limited to invest in eligible assets which are characterized by sufficient liquidity in order to ensure that the fund is in a position to meet potential redemptions. Bilateral transactions that are illiquid by definition require a buy-and-hold investment strategy which may not be suitable for all investment funds.

\subsection{Example}

In the following for the sake of simplicity only a qualitative example is provided, since by comparing the induced costs the CVA hedge already indicates its profitability.

- Bank A holds a portfolio of uncollateralized derivatives (e.g. interest rate swaps (IRS)) with Counterparty B (e.g. a corporate) a netting set is considered. ${ }^{4}$

- Bank A enters into a CVA hedge transaction with Investment Fund C who is taking over credit (counterparty credit risk of $\mathrm{B}$ ) and market risk and provides liquidity with reference to the uncollateralized derivative transaction(s) between Bank A and Counterparty B in terms of the cash collateral postings to Bank A. The transaction between Investment Fund $\mathrm{C}$ and Bank $\mathrm{A}$ is a unilateral (asymmetric) collateral contract in favour of Bank A (and on behalf of Counterparty B). The transaction chart follows Fig. 1.

- In the following table the impact for Bank A with and without CVA hedge is summarized:

With respect to the risk illustrated in the first line in the table above, the CVA hedge transaction mitigates entirely the risk of Bank A by transferring the risk to investment fund C. This results from the posted cash collateral of Investment Fund $\mathrm{C}$ to Bank A on behalf of counterparty C. Comparing the induced costs (second line in the table above) reveals that the (uncollateralized) derivative business is exposed to regulatory and cost of equity charges as well as funding costs. In case of the CVA hedge transaction all these costs are inapplicable, since the posted cash collateral by Investment Fund C to Bank A on behalf of counterparty B leads to entire regulatory capital and cost of capital relief and serves as funding to the derivative exposure between Bank A and counterparty B. On the other hand Bank A pays a fee to Investment Fund $\mathrm{C}$ for taking over the counterparty credit risk of $\mathrm{B}$ and also interest

\footnotetext{
${ }^{4}$ In order to keep legal and operational complexity in an event of default low one netting set is considered.
} 


\begin{tabular}{|l|l|l|}
\hline Bank A & without CVA Hedge & \\
\hline Risk & $\begin{array}{l}\text { - Counterparty Credit Risk of B, } \\
\text { - Market Risk and } \\
\text { - Liquidity/Funding Provision }\end{array}$ & \\
\hline $\begin{array}{l}\text { Induced } \\
\text { Costs }\end{array}$ & $\begin{array}{l}\text { - Costs related to Counterparty Credit Risk B } \\
\text { - Cost of Equity on Regulatory Capital (Basel } \\
\text { II/III charges)) }\end{array}$ & - CVA hedge spread (,fee payment“) \\
& $\begin{array}{l}\text { Costs associated with the Leverage Ratio (Basel } \\
\text { III) }\end{array}$ & \\
& $\begin{array}{l}\text { Costs of Funding costs (depending on Bank A's } \\
\text { rating and funding model assumption) }\end{array}$ & \\
\hline $\begin{array}{l}\text { Cash } \\
\text { Flows }\end{array}$ & $\begin{array}{l}\text { No Default: derivative payments } \\
\text { Default: residual claim times recovery rate }\end{array}$ & $\begin{array}{l}\text { No Default: derivative payments, fee } \\
\text { payment, receive cash collateral, pay } \\
\text { interest on cash collateral, repayment of } \\
\text { collateral at maturity (since exposure } \\
\text { reduces to zero). } \\
\text { Default: physical delivery of residual claim } \\
\text { vs. keeping posted cash collateral and } \\
\text { receiving difference payment up to the } \\
\text { amount of residual claim }\end{array}$ \\
\hline & & \\
& &
\end{tabular}

Fig. 3 Comparison derivatives exposure with and without CVA Hedge transaction from bank A's perspective

on the posted cash collateral. Describing the associated cash flow profiles the two situations, default and non-default of the counterparty, are distinguished (third line in the table above). While in case without CVA hedge structure the cash profiles are straightforward, with CVA hedge transaction in addition fee and interest payments on the collateral have to be considered in the non-default situation. In the event of default of counterparty B, the residual claim of the transaction is physically delivered to Investment Fund $\mathrm{C}$ in return for cash equal to the notional of the residual claim. This procedure follows standard ISDA rules (Fig. 3).

\section{Conclusion}

The new CVA hedging instrument is used in order to transfer counterparty credit risk to entities which are able to manage the risk on an economic basis at lower cost. Investment funds can act as "credit risk taker" and manage counterparty credit exposure at a lower cost than banks, since investment funds are not subject to regulatory capital requirements according to Basel II/III. It has to be noted though that an implementation of the solution described above requires an intense capability and knowledge of dealing with derivatives at the risk taking investment funds. On the other hand, since investment funds are not subject to the same regulations as those for banks described above they may become a natural partner for banks in this context.

The proposed structure bridges the difference between capital rules and financial accounting standards in order to optimize capital requirements and charges for CVA. This is achieved by its liquidity transformation property - the liquidity and credit risk transformation of the counterparty's exposure-and by meeting the Basel II/III and 
IFRS requirements: simultaneous CCR capital and CVA risk charge relief as well as reduced P/L volatility in IFRS resulting from CVA accounting. While the objective outlined herein is predominantly to provide a suitable solution for CVA issues in context of derivatives transactions, it may also create interesting opportunities for investors of the risk taking investment funds.

This solution also contributes to valuation and the discussion on FVA and CVA, since it requires the pricing of the collateral between counterparties "at arm's length". This price determines the discount rate by applying the absence of arbitrage principle. As a consequence FVA is disentangled from CVA by using the proposed structure as a mean.

Acknowledgements The KPMG Center of Excellence in Risk Management is acknowledged for organizing the conference "Challenges in Derivatives Markets - Fixed Income Modeling, Valuation Adjustments, Risk Management, and Regulation".

Open Access This chapter is distributed under the terms of the Creative Commons Attribution 4.0 International License (http://creativecommons.org/licenses/by/4.0/), which permits use, duplication, adaptation, distribution and reproduction in any medium or format, as long as you give appropriate credit to the original author(s) and the source, a link is provided to the Creative Commons license and any changes made are indicated.

The images or other third party material in this book are included in the work's Creative Commons license, unless indicated otherwise in the credit line; if such material is not included in the work's Creative Commons license and the respective action is not permitted by statutory regulation, users will need to obtain permission from the license holder to duplicate, adapt or reproduce the material.

\section{References}

1. Basel Committee on Banking Supervision: International Convergence of Capital Measurement and Capital Standards (2006)

2. Basel Committee on Banking Supervision: Basel III: A Global Regulatory Framework for More Resilient Banks and Banking Systems (2011)

3. Hünseler, M.: Credit Portfolio Management. Palgrave Macmillan, London (2013)

4. International Accounting Standards Board: International Financial Reporting Standards (IFRS) (2015)

5. Schubert, D.: How to hedge CVA without getting hurt, pp. 76-79. Risk Magazine, September Issue (2014) 